\title{
Provincial Situation of Gender Status in Nepal
}

\section{Gopal Khadka}

Lecturer, Department of Rural Development, Patan Multiple Campus, Tribhuvan University, Nepal.

\begin{abstract}
The socio-cultural difference between male and female is termed as gender. Gender is a social construct, which is different from time to time, person to person and place to place. Gender is the cross cutting issue. Gender discrimination has simple cause and event but huge and long-term impact. Gender inequality creates negative multiplier effects on all dimensions of human society. To assess the situation of gender status and to identify causes, consequences and measures of gender inequality, this article is prepared as the title 'provincial situation of gender status in Nepal'. It is mainly based on the secondary data of Nepal Multiple Indicator Cluster Survey, which was conducted by the Central Bureau of Statistics in 2019. Information regarding objectives was collected through various search engines by simple literature review. The status of gender is found unequal at provincial level in Nepal. Among eight indicators, men are in good situation than women in educational status, exposure to mass media, condition of child marriage and knowledge of human trafficking,. The situation of better life and perception of domestic violence have a zigzag result. It shows somehow a better situation for both men and women. In health conscious matters i.e. use of tobacco and drink of alcoholic products, the situation of females is better than male. To meet national commitment in gender mainstreaming and to fulfill the target of sustainable development goals, it is essential to perform effective joint efforts of all concerned authorities as soon as possible with the visionary and coordinating leadership of the federal government.
\end{abstract}

Keywords_- province, gender, gender equality, gender mainstreaming, human trafficking.

\section{INTRODUCTION}

Women and girls, everywhere, must have equal rights and opportunities, and be able to live free of violence and discrimination (UN, 2018). In goal-5, Sustainable Development Goals focus to achieve gender equality and empower all women and girls. Women empowerment boosts up economic production and productivity. It gears up socio cultural transformation. Provision of gender equality respects and treats male and female in equal manner. It guaranteed the basic human right. Gender equality by 2030 requires urgent action to eliminate the many root causes of discrimination that still curtail women's rights in private and public spheres (UN, 2018).

The human right protection and promotion of gender equality requires more than numerical equilibrium, it also requires conceptual equilibrium and conscientious effort to redress inequality, as it exists (Wilson, 2004). Gender equality is the need of time. It is the vital concern of women all over the world. Development requires equal efforts from two halves of world population. Development becomes successful, if it distributes its fruit for all section of society without any discrimination. Article 43 of the federal constitution of Nepal 2015 deals with the rights of women that include rights to lineage, right to safe maternity and reproduction, right against all forms of exploitation, and equal rights in family matters and property. The Government of Nepal is developing a gender responsive development plan and policies to maintain gender equality in all dimensions of social life. Gender responsive budget system, gender auditing, gender mainstreaming etc. are some of the notable endeavor of Nepal government to fulfill the gender related commitment in national and international forum.

While more women have entered political positions in recent years, including through the use of special quotas, they still hold a mere 23.7 percent of parliamentary seats, far short of parity. The situation is not much better in the private sector, where women globally occupy less than a third of senior and middle management positions (UN, 2017). Women lack access to decent work and face occupational segregation and gender wage gaps. They are too often denied access to basic 
education and health care. Women in all parts of the world suffer violence and discrimination. They are underrepresented in political and economic decision-making processes. (UN, 2018)

Gender is a social construct and discrimination on this basis is consequently difficult to assess and address. Gender differentials entail more subtle distinctions on male and female roles (Wilson, 2004). Gender is the subjective term. The cause and consequences of gender inequality are different in different times and places. Nepal adopted patriarchal values and principles highly in all dimensions of social and family life. There is limited access to social opportunity for women. Gender bias social norms, values and practices are responsible to create adverse effects on women's life form. Nepal is a new federal democratic country on this globe. It introduces federal system of governance to remove all types of discrimination and create egalitarian society to maximize equal opportunity for all. Nepal has 7 provinces i.e. province-1, province-2, Bagmati province, Gandaki province, province-5, Karnali province and sudoor pashchim province. Three tiers of government i.e. federal government, provincial government and local government are jointly fighting against gender related discrimination. It is essential to assess the government effort in this field to provide feedback and monitor the governmental initiation.

The current periodic plan of Nepal also recognizes the need to adopt an inclusive development process that ensures the access and participation of excluded groups and has set quantitative targets to achieve this. Yet, genuine inclusion and effective implementation of inclusive policies remain key development challenges .Nepal has also taken on a number of international commitments to nondiscrimination, gender equality, and social justice. These include the Convention on the Elimination of all Forms of Discrimination against Women, The Beijing Platform for Action (1995), The Millennium Development Goals (2000), The Sustainable Development Goals (2015) and United Nations Security Council Resolution 1325, International conventions such as the Convention on the Elimination of All Forms of Discrimination etc (ADB,2010).

By considering the role of gender status in socio economic life, this article tries to reveal the provincial situation of gender status in Nepal based on secondary data of the central bureau of statics. It is mainly based on the key indicators of Nepal Multiple Indicator Cluster Survey it tries to analyze the notable factors responsible for gender inequality and its measures. It provides valuable information for the concerned agencies and personnel to understand the current situation of gender status on selected variables in Nepal.

\section{OBJECTIVES}

The article is based on following two objectives:

- To assess the situation of gender status of Nepal at the provincial level.

- To identify cause, consequences and measures to maintain gender equality in Nepal.

\section{MATERIAL AND METHODS}

Central Bureau of Statistics (CBS) is the central governmental agency for the collecting, processing, analyzing, publishing and disseminating various data and information of Nepal. It is under the National Planning Commission Secretariat of Nepal and serves as a national statistical organization of the Government of Nepal. By conducting censuses and surveys, it generates timely, reliable and valid statistics of multiple dimensions. The Multiple Indicator Cluster Survey (MICS) is an international household survey program developed and supported by UNICEF. MICS is designed to collect estimates of key indicators that are used to assess the situation of children and women. Nepal MICS 2019 was conducted by the Central Bureau of Statistics from May to November 2019 as a part of sixth-round of the global MICS household program, with the technical and financial support from United Nations Children's Fund (UNICEF) Nepal. NMICS-2019 provides valuable information and the latest evidence on the situation of children and women in Nepal. (CBS, 2020). This article is mainly based on the secondary data of Nepal Multiple Indicator Cluster Survey (NMICS-2019). Information regarding objectives was collected through various search engines by simple literature review. Data is analyzed descriptively through the use of tables.

\section{RESULT AND DISCUSSION}

\subsection{Educational status}

Education is considered as life blood in the human body, which circulates to deliver essential things and dispose unnecessary things from our body. Education aware about the causes, consequences and preventive measures of personal and social problems related to human life. 
Education is the backbone and inner light of human life. By education paved the way of development and civilization. creating positive and constructive changes in human life,

Table -1: Literacy Rate of Men and Women

\begin{tabular}{|l|l|l|l|l|l|l|l|l|l|}
\hline MICS & Category & \multirow{2}{*}{$\begin{array}{l}\text { Indicator } \\
\end{array}$} & & & \multicolumn{7}{|c|}{ Provinces } \\
\cline { 5 - 10 } & & & Province1 & Province2 & Bagmati & Gandaki & Province5 & Karnali & Sudoor pashchim \\
\hline Literacy & Total & 90.3 & 92.9 & 77.1 & 96.1 & 97.1 & 87.6 & 94.3 & 93.9 \\
\cline { 2 - 10 } & Women & 88.2 & 91.4 & 70.6 & 94.6 & 97.1 & 87.3 & 92.8 & 92.3 \\
\cline { 2 - 10 } & Men & 92.7 & 94.9 & 84.8 & 97.5 & 97.2 & 87.9 & 96.4 & 96.1 \\
\hline
\end{tabular}

Data Source: NMICS- 2019, CBS

Table-1 indicates the Percentage of women and men aged 1524 years who are able to read a short simple statement about everyday life or who attended secondary or higher education. The educational status of a country is measured by literacy rate. Literacy rate is the component of human development index and SDGs. According to table-1, the literacy rate of male is higher than female in all provinces. In province-2, the literacy gap between male and female is wider and in Gandaki province, it is narrower. Concerned authority should focus to uplift the overall status of education especially girl education in province- 2 .

Girl education is the long term investment of the nation to tackle poverty and backwardness. Girl education is directly proportional to sustainable development. Public awareness about the importance of girl education, control of child marriage, strict regulation of child labor, safety concerns of girls, separate girl toilet, various scheme of incentives, Informal education system, education through mother tongue, Remoteness of school, gender responsive education policy, provision of Qualified female teacher, gender friendly classroom etc are the main issues to be addressed for the promotion of educational status in Nepal.

\subsection{Exposure to Mass Media}

Mass media is the main source of information for the people. The media acts as the message and the messenger. It can push gender discrimination to complicated level. It can play the catalytic role to eradicate the issues of gender inequalities. Mass media can play vital role for the empowerment of women. Today's world is the world of communication and information. Through mass media, women can get information about job opportunities, career advancement, education and training, health and hygiene, nutrition and diseases, legal provision about gender biased activities like sexual harassment, social injustice, domestic violence, dowry system etc.

Table -2: Exposure to Mass Media

\begin{tabular}{|c|c|c|c|c|c|c|c|c|c|}
\hline \multirow{2}{*}{$\begin{array}{l}\text { MICS } \\
\text { Indicators }\end{array}$} & \multirow[t]{2}{*}{ Category } & \multirow[t]{2}{*}{ Nepal } & \multicolumn{7}{|c|}{ Provinces } \\
\hline & & & Province 1 & Province2 & Bagmati & Gandaki & Province5 & Karnali & Sudoor pashchim \\
\hline \multirow{3}{*}{$\begin{array}{l}\text { Exposure } \\
\text { to Mass } \\
\text { Media }\end{array}$} & Total & 8.0 & 8.3 & 5.0 & 12.3 & 8.8 & 5.4 & 3.4 & 7.6 \\
\hline & Women & 4.1 & 3.8 & 1.8 & 8.0 & 6.8 & 1.9 & 0.8 & 1.7 \\
\hline & Men & 12.9 & 13.9 & 8.9 & 17.2 & 12.0 & 10.1 & 7.1 & 16.0 \\
\hline
\end{tabular}

Data Source: NMICS- 2019, CBS

Table- 2 reveals Percentage of women and men age 15-49 years who, at least once a week, read a newspaper or magazine, listen to the radio, and watch television.
According to this table, we can observe that there is vast difference between male and female. Male has more access and control over mass media. The gender gap with access to 
mass media is wider in sudoorpashchim province and narrower in Gandaki province. The women of Bagmati province have more access and Karnali province have low access in mass media.

Mass media is the informal means of education. It is an effective and efficient mechanism of public awareness about almost all issues of society. To increase women literacy rate; to empower women; to increase women awareness; to eradicate gender inequality; to uplift the low status of women, Necessary action must be performed in Nepal to increase the access and control of women in mass media.

\subsection{Domestic Violence}

Violence against women, is widespread, occurs in nearly every country and every culture. In many parts of the world, the marital relationship has the dominance of husband, dependence and obedience of wife who submits/surrenders at the cost of own advancement, self-esteem, and even health. Gender inequalities in everyday life, work, responsibilities, and a form of violence remain invisible. Violence means 'Act that causes or has the potential to cause physical, mental harm and is rooted in gender inequality (Chhabra, 2018).

Table-3: Attitudes towards Domestic Violence

\begin{tabular}{|c|c|c|c|c|c|c|c|c|c|}
\hline \multirow{2}{*}{$\begin{array}{l}\text { MICS } \\
\text { indicators }\end{array}$} & Category & Nepal & \multicolumn{7}{|c|}{ Provinces } \\
\cline { 4 - 10 } & & & Province1 & Province2 & Bagmati & Gandaki & Province5 & Karnali & Sudoor pashchim \\
\hline $\begin{array}{c}\text { Attitudes } \\
\text { towards }\end{array}$ & Total & 29.5 & 27.3 & 40.2 & 25.9 & 25.4 & 28.3 & 22.5 & 32.8 \\
\cline { 2 - 10 } $\begin{array}{c}\text { Domestic } \\
\text { Violence }\end{array}$ & Women & 29.5 & 30.2 & 33.7 & 29.5 & 28.0 & 26.4 & 17.5 & 35.0 \\
\cline { 2 - 10 } & Men & 29.4 & 23.7 & 48.2 & 21.7 & 20.8 & 30.8 & 29.6 & 29.7 \\
\hline
\end{tabular}

Data Source: NMICS- 2019, CBS

Table- 3 reveals that Percentage of women and men aged 1549 years who state that a husband is justified in hitting and beating his wife in at least one of the following circumstances: (1) she goes out without telling him; (2) she neglects the children; (3) she argues with him; (4) she refuses sex with him; and (5) she burns the food. Due to the unequal socio, economic, political and cultural status, the attitude towards domestic violence between men and women are unequal in all provinces. Women in province-1, Bagmati province, Gandaki province and Sudoor pashchim province are more tolerated than province-2, province- 5 and Karnali province in terms of domestic violence.

Gender responsive activities help to control the violence in family and society. Family, community, school, mass media etc can play an active and interventionist role to control violence and promote gender equality. When gender roles become more flexible, most women enjoy greater power, status and economic independence and the threat of violence against them decreases. It is important, therefore, to engage both men and women and boys and girls in interventions that promote gender equality and prevent violence against women. (Archer, 2006).

\subsection{Human Trafficking}

Human Trafficking is an emerging issue of Nepal. It is a complex issue. It emerges due to the economic, social and environmental crisis. Mainly poverty is responsible to create the complexity of human trafficking. The main cause of human trafficking is extreme desire of people to escape from vicious circle of poverty. In the context of Nepal Domestic work, agricultural work, construction labor, carpet and garment industries, organized begging, forced marriage and prostitution are listed as common factors responsible to increase human trafficking. 
International Journal of English Literature and Social Sciences, 5(4)

Jul-Aug 2020 /Available online: https://ijels.com/

Table-4: Perception towards Human Trafficking

\begin{tabular}{|l|l|l|l|c|c|c|c|c|c|}
\hline \multirow{2}{*}{$\begin{array}{l}\text { MICS } \\
\text { indicators }\end{array}$} & Category & Nepal & \multicolumn{7}{|c|}{ Provinces } \\
\cline { 4 - 10 } & & & Province1 & Province2 & Bagmati & Gandaki & Province5 & Karnali & Sudoor pashchim \\
\hline $\begin{array}{c}\text { Perception } \\
\text { towards }\end{array}$ & Total & 79.4 & 82.5 & 63.7 & 91.1 & 88.1 & 73.3 & 66.9 & 82.6 \\
\cline { 2 - 10 } $\begin{array}{c}\text { Human } \\
\text { Trafficking }\end{array}$ & Women & 72.2 & 80.5 & 48.1 & 87.2 & 85.3 & 64.4 & 55.1 & 77.4 \\
\cline { 2 - 10 } & Men & 88.4 & 85.1 & 82.9 & 95.7 & 92.2 & 85.1 & 83.4 & 90.2 \\
\hline
\end{tabular}

Data Source: NMICS- 2019, CBS

Table-4 reveals that Percentage of women and men aged 1549 years who have heard about human trafficking. In case of human trafficking, men are more aware than women .This situation is the result of high literacy rate and more control of mass media by men than women in Nepal.Women are adversely victimized in human trafficking. It is anti-human and illegal activities. Women in province- 2 and province- 5 are less aware then other provinces about human trafficking. By realizing negative consequences, Nepal government should make effective effort to control human trafficking with the focus to increase public awareness, increase literacy rate, women empowerment, poverty reduction, job creation in all provinces.

\subsection{Child Marriage}

The practice of union between boy and girl formally and informally before the age of 18 is termed as child marriage. The rate of child marriage is very high in Nepal compare to other Asian countries. The number of girls is higher than boys in the case of child marriage. It affects girls more badly than boys. Child brides are at greater risk of experiencing a range of poor health outcomes, having children at younger ages when they are not yet ready to do so, dropping out of school, earning less over their lifetimes and living in poverty compared to their peers who marry at later ages. Most fundamentally, child brides may be disempowered in ways that deprive them of their basic rights to health, education and safety. These dynamics affect not only the girls themselves, but also their children and households, as well as communities and entire societies. (Wodon et al., 2017)

Table-5: Percentage of Men and Women Regarding Child Marriage

\begin{tabular}{|c|c|c|c|c|c|c|c|c|c|}
\hline \multirow[t]{2}{*}{ MICS indicators } & \multirow[t]{2}{*}{ Category } & \multirow[t]{2}{*}{ Nepal } & \multicolumn{7}{|c|}{ Provinces } \\
\hline & & & Province1 & Province 2 & Bagmati & Gandaki & Province5 & Karnali & Sudoor pashchim \\
\hline \multirow{3}{*}{$\begin{array}{l}\text { Young people } \\
\text { age 15-19 years } \\
\text { currently } \\
\text { married or in } \\
\text { union }\end{array}$} & Total & 12.8 & 8.9 & 15.2 & 9.6 & 14.7 & 13.9 & 20.5 & 13.3 \\
\hline & Women & 19.3 & 14.7 & 24.9 & 13.7 & 23.1 & 20.1 & 27.4 & 18.8 \\
\hline & Men & 5.3 & 2.5 & 4.4 & 4.8 & 4.3 & 6.3 & 12.1 & 7.0 \\
\hline
\end{tabular}

Data Source: NMICS- 2019, CBS

Table-5 reveals the Percentage of women and men aged 1519 years who are married or in union. The percentage of women is four fold than men in terms of child marriage. Child marriage of girl is higher in Karnali province followed by province- 2 and Gandaki province. Parental pressure, traditional practices, reducing family burden, low burden of dowry, commodity value of girl, social taboos, ineffective implementation of law, gender inequality, illiteracy etc are the responsible factors of child marriage in Nepal. By adopting different formal and informal measures, Nepal government struggle to fight against child marriage .Among various measures, public awareness and strict implementation of law play effective role in this case. 
4.6 Use of Tobacco and Alcohol

Tobacco and alcohol are openly used in Nepal. Both substances create problems in human health. They create social, economic and behavioral problems. People reported various reasons for starting their smoking and drinking habits.

Table-6: Use of Tobacco and Alcohol

\begin{tabular}{|l|c|c|c|c|c|c|c|c|c|}
\hline MICS Indicators & Category & Nepal & \multicolumn{7}{|c|}{ Provinces } \\
\cline { 4 - 10 } & & & Province1 & Province2 & Bagmati & Gandaki & Province5 & Karnali & Sudoor- pashchim \\
\hline Use of Tobacco & Total & 23.3 & 25.3 & 23.0 & 20.3 & 19.8 & 26.5 & 24.1 & 25.4 \\
\cline { 2 - 11 } & Women & 6.1 & 6.0 & 2.7 & 5.4 & 6.2 & 8.0 & 11.0 & 8.0 \\
\cline { 2 - 11 } & Men & 45.2 & 49.0 & 48.2 & 37.4 & 40.2 & 50.9 & 42.5 & 50.4 \\
\hline Use of Alcohol & Total & 23.0 & 26.8 & 11.3 & 29.4 & 24.9 & 24.5 & 14.8 & 20.3 \\
\cline { 2 - 10 } & Women & 9.1 & 13.5 & 1.0 & 14.8 & 9.7 & 9.4 & 2.4 & 3.7 \\
\cline { 2 - 10 } & Men & 40.6 & 43.1 & 24.0 & 46.1 & 47.5 & 44.5 & 32.2 & 43.9 \\
\hline
\end{tabular}

Data Source: NMICS- 2019, CBS

Table-6 indicates Percentage of women and men aged 15-49 years who smoked cigarettes or used smoked or smokeless tobacco products and drink at least one alcoholic product at any time during the last one month. It signifies health consciousness. Women of province- 2 are more conscious to use tobacco and alcohol compared with other provinces. Women are more conscious of their health than men in all provinces according to use of tobacco and alcoholic products. There is no correlation between literacy rate and use of tobacco or alcohol. Literacy rate and rate of tobacco or alcohol use, both are high in men all over the country. From the gender perspective, necessary steps must be taken for men to reduce the use of tobacco or alcohol.

\subsection{Perception of a Better Life}

Generally better life requires fulfilling all needs and demands of individual life. It indicates life with happiness and satisfaction. It concerns basic needs and additional needs of people. It is directly related with food, cloth, shelter, income, job, health status, education, love, security, governance etc. The situation of a better life creates happiness that leads to a successful life.

Table-7: Perception of a Better Life

\begin{tabular}{|l|c|c|c|c|c|c|c|c|c|}
\hline MICS Indicators & Category & Nepal & \multicolumn{9}{|c|}{ Provinces } \\
\cline { 4 - 10 } & & & Province1 & Province2 & Bagmati & Gandaki & Province5 & Karnali & $\begin{array}{c}\text { Sudoor } \\
\text { pashchim }\end{array}$ \\
\hline $\begin{array}{l}\text { Perception of a } \\
\text { Better Life }\end{array}$ & Total & 48.5 & 36.2 & 49.1 & 56.3 & 56.3 & 47.5 & 42.5 & 46.1 \\
\cline { 2 - 11 } & Women & 45.5 & 36.3 & 47.8 & 46.4 & 54.2 & 46.0 & 39.7 & 49.1 \\
\cline { 2 - 10 } & Men & 52.5 & 36 & 50.8 & 67.7 & 59.6 & 49.5 & 46.5 & 41.7 \\
\hline
\end{tabular}

Data Source: NMICS-2019, CBS

Table-7 indicates Percentage of women and men aged 15-49 years, whose life improved during the last one year and who expect that their life will be better after one year. The perception of a better life is found higher in Gandaki province for women and in Bagmati province for men. The perception of better life is found lower in province-1 for 
women and men. Gender gap in the perception of a better life is wider in Bagmati province and narrower in province1.It is essential to create a favourable environment to maintain equal and higher perception between men and women about the better life by focusing the factors responsible for quality of life.

\section{CONCLUSION}

On the basis of educational status, exposure to mass media, human trafficking, domestic violence, situation of child marriage, use of tobacco, drink of alcohol and perception of better life, this article explore that the status of gender is unequal in all provinces of Nepal. The cause, consequences and measures of gender inequality are varied in various social, economic and cultural contexts of provinces. To meet national commitment in gender equality and to fulfill the target of sustainable development goals, it is essential to perform effective joint efforts of all concerned authorities as soon as possible. Gender inequality is the root cause of violence against women. Miserable status of women cannot pave the way for development. To meet all goals of SDGs, one simple step of individual and family for gender mainstreaming can play a giant role. Three tiers of government in Nepal i.e. federal government, provincial government and local government must prepare a gender responsive budget strategically to get rid of sinful acts of gender inequality. The issue of Gender inequality must be addressed to ensure overall development of the nation.

\section{REFERENCES}

[1] Archer J. (2006). Cross-cultural differences in physical aggression between partners: a social-role analysis. Personality and Social Psychology Review, 2006, 10(2):133-53.

[2] Asian Development Bank. (2010). Overview of gender equality and social inclusion in Nepal. Mandaluyong City. Philippines.

[3] Central Bureau of Statistics. (2020). Nepal Multiple Indicator Cluster Survey 2019. CBS, Nepal Planning Commission. Kathmandu: Government of Nepal. https://cbs.gov.np/nmic2019-key-report

[4] Chhabra, S. (2018). Effects of Societal/Domestic Violence on Health of Women. J Women's Health Reprod Med. Vol.2 No.1:6

[5] UN Economic and Social Council. (2017). Progress towards the Sustainable Development Goals: Report of the SecretaryGeneral (E/2017/66).

[6] UN, women. (2018). turning promises into action: gender equality in the 2030 agenda for sustainable development
[7] USAID. (1999). "USAID Strategic Treatment for the Asia Regional Anti-Trafficking Initiative.”. May 25, 1999 draft. Washington, D.C., USA.

[8] Wilson, D. (2004). Human Rights: Promoting Gender Equality in and through Education PROSPECTS 34, 11-27 (2004). https://doi.org/10.1023/B:PROS.0000026677.67065.84

[9] Wodon, Q., Tavares, P., Fiala, O., Le Nestour, A., \& Wise, L. (2017). Ending Child Marriage: Legal Age for Marriage, Illegal Child Marriages, and the Need for Interventions. London and Washington, DC: Save the Children and The World Bank. 